\title{
A fibrolytic enzyme additive for lactating Holstein cow diets: Ruminal fermentation, rumen microbial populations, and enteric methane emissions
}

\author{
Y.-H. Chung, ${ }^{\star}$ M. Zhou, $\dagger$ L. Holtshausen, ${ }^{*}$ T. W. Alexander, ${ }^{*}$ T. A. McAllister, ${ }^{\star}$ L. L. Guan, $\dagger$ M. Oba, $\dagger$ \\ and K. A. Beauchemin ${ }^{* 1}$ \\ ${ }^{*}$ Research Center, Agriculture and Agri-Food Canada, Lethbridge, Alberta T1J 4B1, Canada \\ †Department of Agricultural, Food and Nutritional Science, University of Alberta, Edmonton, Alberta T6G 2P5, Canada
}

\begin{abstract}
The objective was to determine if supplementing a dairy cow diet with an exogenous fibrolytic enzyme additive (Econase RDE; AB Vista, Marlborough, Wiltshire, UK) altered fermentation, $\mathrm{pH}$, and microbial populations in the rumen or enteric methane $\left(\mathrm{CH}_{4}\right)$ emissions. In a companion study, this enzyme additive improved efficiency of fat-corrected milk production in a dosedependent manner by up to $11 \%$ for early lactation dairy cows. Nine ruminally cannulated, lactating Holstein cows were used in a replicated $3 \times 3$ Latin square design with 21-d periods. Dietary treatments were 0 (control), 0.5 (low), and 1.0 (high) $\mathrm{mL}$ of enzyme $/ \mathrm{kg}$ of total mixed ration dry matter. Rumen contents were collected on $2 \mathrm{~d}$ (d 15 and 19), ruminal $\mathrm{pH}$ was measured continuously for $6 \mathrm{~d}$ (d 13 to 18) by using an indwelling system, and enteric $\mathrm{CH}_{4}$ production was measured for $3 \mathrm{~d}$ (d 16 to 18) using the sulfur hexafluoride tracer gas technique. The enzyme additive did not alter volatile fatty acids, $\mathrm{NH}_{3}, \mathrm{pH}$, or population densities of total protozoa, bacteria, and methanogens in ruminal fluid. However, population densities of certain bacteria, calculated as copy number of species-specific 16S-rRNA, were affected by enzyme treatment. Population density of Ruminobacter amylophilus was increased and that of Fibrobacter succinogenes tended to be increased by the high enzyme treatment. Selenomonas ruminantium tended to increase linearly with increasing levels of enzyme in the diet, although its population density was only numerically increased by the high enzyme treatment. Streptococcus bovis, however, tended to be decreased by the low enzyme treatment. Increasing the level of enzyme supplement in the diet also linearly increased enteric $\mathrm{CH}_{4}$ production, even when adjusted for feed intake or milk production (19.3, 20.8, and 21.7 $\mathrm{g}$ of $\mathrm{CH}_{4} / \mathrm{kg}$ of dry matter intake or $12.9,13.6$, and $15.1 \mathrm{~g}$ of $\mathrm{CH}_{4} / \mathrm{kg}$ of milk for the control, low, and high
\end{abstract}

Received May 19, 2011.

Accepted November 14, 2011

${ }^{1}$ Corresponding author: karen.beauchemin@agr.gc.ca enzyme treatments, respectively). This shift in ruminal bacterial communities and higher $\mathrm{CH}_{4}$ emissions could imply increased ruminal digestion of feed, which needs to be substantiated in longer term studies.

Key words: exogenous fibrolytic enzyme additive, ruminal bacteria, enteric methane emission, sulfur hexafluoride tracer gas technique

\section{INTRODUCTION}

Increases in feed costs continue to fuel interest in improving the production efficiency of dairy cows, and enzyme feed additives with fibrolytic activities offer a possible means of enhancing forage digestion and feed conversion efficiency. A range of effects of using fibrolytic enzymes in ruminant diets has been reported (Beauchemin and Holtshausen, 2011). Some enzyme formulations increased DMI, in vivo fiber digestibility, and milk production of dairy cows, whereas many other studies reported no effects. Responses to enzyme additives vary depending upon the type of animals (energy requirement of the animal and level of feeding), diet composition, enzyme formulation, dose rate, and delivery method of enzyme products (Beauchemin and Holtshausen, 2011).

Recently, some exogenous fibrolytic enzyme products were reported to increase milk production efficiency in early to mid lactation dairy cows (Arriola et al., 2011; Holtshausen et al., 2011). This increased milk production efficiency was a result of a numerical decrease in feed intake with no change in milk yield in cows fed diets supplemented with enzymes. Arriola et al. (2011) related the improvement in feed conversion efficiency to increased total-tract digestibility, although in situ ruminal degradability was not affected. Holtshausen et al. (2011) attributed the improvement in milk production efficiency to an increase in fiber digestibility (based on in vitro assay) of dietary forages. However, ruminal fermentation responses were not measured in that study. Arriola et al. (2011) also reported a similar level of milk production for cows fed an enzyme-treated, high-forage diet $(67 \%$ diet DM) compared with cows fed an un- 
treated, low-forage diet ( $52 \%$ diet DM). Based on these findings, the use of certain enzyme additives may allow dairy producers to feed higher forage diets or high-fiber byproduct feeds without compromising energy intake and milk production of the cow.

Increased substrate degradability by fibrolytic enzyme additives reported in in vitro evaluations (Eun et al., 2007; Eun and Beauchemin, 2007) has often been accompanied by concurrent decreases in acetate:propionate ratios in the incubation fluids. The formation of propionate serves as an $\mathrm{H}_{2}$ sink in ruminal fermentation, and a greater proportion of propionate and (or) a lower acetate:propionate ratio in ruminal fluid could indicate a lower availability of metabolic $\mathrm{H}_{2}$ for methanogenesis. Based on this observation, Beauchemin et al. (2008) proposed supplementing ruminant diets with enzyme feed additives as a means of mitigating enteric methane $\left(\mathrm{CH}_{4}\right)$ production. Giraldo et al. (2008a) reported that $\mathrm{CH}_{4}$ production corrected for the amount of OM degraded was decreased when fibrolytic enzymes were added to the substrates during an in vitro incubation. In an in vivo study (Arriola et al., 2011), a decrease in the calculated enteric $\mathrm{CH}_{4}$ production was reported for a lactating cow diet $(52 \%$ dietary forage) supplemented with a fibrolytic enzyme additive. A decreased acetate:propionate ratio was reported in both of the studies.

Hence, this study was conducted to obtain further information on the potential mode of action of the enzyme additive used by Holtshausen et al. (2011), in which milk production efficiency of lactating dairy cows was increased with the use of an exogenous fibrolytic enzyme additive. The objective was to determine the effects of supplementing a dairy cow diet with a fibrolytic enzyme additive on fermentation, $\mathrm{pH}$, and microbial populations in the rumen and enteric $\mathrm{CH}_{4}$ emissions.

\section{MATERIALS AND METHODS}

\section{Experimental Design, Dietary Treatments, and Animal Care}

Nine ruminally cannulated, lactating Holstein cows (5 multiparous and 4 primiparous) were used in a replicated $3 \times 3$ Latin square design with 21 -d periods. Cows were blocked into 3 groups (i.e., squares) on the basis of pre-experimental DIM (means \pm SD: group 1 $=51 \pm 8.6$, group $2=56 \pm 7.5$, and group $3=130$ $\pm 36.8)$. Pre-experimental milk yields for the 3 groups were at (means $\pm \mathrm{SD}$ ) $41.8 \pm 6.0,22.7 \pm 12.5$, and $46.6 \pm 5.4 \mathrm{~kg} / \mathrm{d}$ for group 1 to 3 , respectively. Dietary treatments were 0 (control), 0.5 (low), and 1.0 (high) $\mathrm{mL}$ of enzyme $/ \mathrm{kg}$ of TMR DM.
The basal diet (i.e., the control diet; $48: 52$ forage to concentrate ratio; Table 1) was formulated to provide adequate ME and MP for a $605-\mathrm{kg}$ cow producing 39 $\mathrm{kg} / \mathrm{d}$ of milk containing $3.5 \%$ fat and $3.3 \%$ protein and assuming a DMI of $23 \mathrm{~kg} / \mathrm{d}$ using the Cornell-PennMiner System (CPM Dairy, version 3.0.4a; Cornell University, Ithaca, NY; University of Pennsylvania, Kennett Square, PA; and William H. Miner Agricultural Research Institute, Chazy, NY). The exogenous fibrolytic enzyme additive (Econase RDE; AB Vista, Marlborough, Wiltshire, UK) was obtained from a single batch and contained $722 \mathrm{nmol} / \mu \mathrm{L}$ (i.e., nmol of glucose equivalents/min per $\mu \mathrm{L}$ of the enzyme product) of endoglucanase (EC 3.2.1.4) and 2,604 nmol/ $\mu \mathrm{L}$ (i.e., nmol of xylose equivalents/min per $\mu \mathrm{L}$ of the enzyme product) of xylanase (EC 3.2.1.8) activity, with activity determined at $39^{\circ} \mathrm{C}$ and $\mathrm{pH} 6.0$ using low viscosity carboxymethyl cellulose (catalog no. C-5678; Sigma Chemical Co., St. Louis, MO) and birchwood xylan (catalog no. X-0502; Sigma Chemical Co.) as substrates for endoglucanase and xylanase, respectively. The enzyme additive (i.e., $100 \mathrm{~mL}$ of the enzyme additive per $100 \mathrm{~kg}$ of TMR DM for the high enzyme treatment) was first diluted in $4 \mathrm{~L}$ of water, and the dilution was added to the TMR at the time of mixing, usually within $1 \mathrm{~h}$ before feeding. An equal amount of water $(4 \mathrm{~L} / 100 \mathrm{~kg}$ of TMR DM) was added to the control diet. Experimental diets were fed to cows for ad libitum intake once daily at $0800 \mathrm{~h}$. Cows were milked in their stalls twice daily at 0400 and $1400 \mathrm{~h}$.

During each experimental period, d 1 to 14 were used to adapt cows to their assigned experimental diets (the full experimental diets were introduced on d 1 of each period). Rumen contents were collected on d 15 and 19 , ruminal $\mathrm{pH}$ was measured continuously from d 13 to 18 , and enteric $\mathrm{CH}_{4}$ production was measured from d 16 to 18 . This study was conducted separately but at the same time as that reported by Holtshausen et al. (2011) and used the same basal diet and enzyme treatments. Details of animal housing and care were reported in Holtshausen et al. (2011).

\section{Measurements}

Daily intakes and refusals of the experimental diets for individual cows were recorded. The refusals for individual cows were sampled twice each week during wk 1 and 2 and from Monday to Friday during wk 3 (the sampling week) of each period and composited by week. Experimental diets and dietary ingredients were sampled twice weekly and composited by week. Weekly refusals, experimental diets, and ingredients were stored at $-20^{\circ} \mathrm{C}$ until analyzed. 
Table 1. Ingredients and chemical composition (mean \pm SD) of the basal diet (no enzyme added)

\begin{tabular}{lc}
\hline Item & $\begin{array}{c}\text { \% of } \\
\text { diet DM }\end{array}$ \\
\hline Ingredient $^{1}$ & \\
Barley silage $^{2}$ & 20.6 \\
Alfalfa silage $^{3}$ & 20.6 \\
Alfalfa hay $^{4}$ & 10.8 \\
Ground concentrate mixture $^{5}$ & 48.0 \\
Chemical composition & $52.9 \pm 3.62$ \\
DM & $89.5 \pm 0.56$ \\
OM, \% of DM & $20.0 \pm 1.00$ \\
CP, \% of DM & $33.9 \pm 1.82$ \\
NDF, \% of DM & $23.9 \pm 1.49$ \\
ADF, \% of DM &
\end{tabular}

${ }^{1}$ All ingredients except barley silage, alfalfa silage, and alfalfa hay were provided as part of a ground concentrate mixture.

${ }^{2}$ Composition (DM basis): $35.3 \% \mathrm{DM}, 15.0 \% \mathrm{CP}, 53.2 \% \mathrm{NDF}$, and $34.2 \% \mathrm{ADF}$.

${ }^{3}$ Composition (DM basis): $39.8 \%$ DM, $18.9 \% \mathrm{CP}, 37.2 \% \mathrm{NDF}$, and $32.2 \% \mathrm{ADF}$.

${ }^{4}$ Composition (DM basis): $89.5 \%$ DM, $16.8 \% \mathrm{CP}, 47.4 \% \mathrm{NDF}$, and $36.6 \%$ ADF.

${ }^{5}$ Mixture contained (diet DM basis) 9.52\% steam-rolled barley grain, $8.88 \%$ steam-rolled corn grain, $6.60 \%$ bypass soybean meal (Amino Plus, Ag Processing Inc., Omaha, NE), 6.00\% dry ground corn, $5.16 \%$ dry ground barley, $4.32 \%$ soybean meal, $3.36 \%$ corn distillers grain with solubles, $2.52 \%$ canola meal, $0.41 \%$ limestone, $0.39 \%$ sodium bicarbonate, $0.33 \%$ salt, $0.19 \%$ magnesium oxide, $0.17 \%$ dicalcium phosphate, and $0.15 \%$ trace mineral premix (added to supply per $\mathrm{kg}$ of dietary DM: $65 \mathrm{mg}$ of $\mathrm{Mn}, 110 \mathrm{mg}$ of $\mathrm{Zn}, 37 \mathrm{mg}$ of $\mathrm{Cu}, 1 \mathrm{mg}$ of Co, $0.30 \mathrm{mg}$ of Se, 8,336 IU of vitamin A, $834 \mathrm{IU}$ of vitamin D, and $56 \mathrm{IU}$ of vitamin $\mathrm{E})$.

Milk was sampled from 6 consecutive milkings from d 15 to 18 of each period. Evening and morning milk samples were analyzed separately, and milk composition was calculated accounting for different milk yields between evening and morning milkings. Cows were weighed for 2 consecutive days and BCS assessed (Wildman et al., 1982) at the beginning of each period and at the end of the experiment.

A composite sample of rumen contents was obtained from 5 sites within the rumen (cranial dorsal, cranial ventral, central rumen, caudal dorsal, and caudal ventral locations) at 0,6 , and $12 \mathrm{~h}$ after feeding on d 15 and 19. Rumen contents were thoroughly mixed and filtered through 2 layers of polyester monofilament fabric (Pecap 7-255/47, mesh opening $355 \mu \mathrm{m}$; Tetko Inc., Scarborough, ON, Canada). Aliquots of the filtrates were stored on dry ice and then at $-80^{\circ} \mathrm{C}$ until analyzed for bacteria and methanogens or stored at $-20^{\circ} \mathrm{C}$ until analyzed for VFA by mixing $5 \mathrm{~mL}$ of the filtrate with $1 \mathrm{~mL}$ of $25 \%$ (wt/vol) $\mathrm{HPO}_{3}$ ] and $\mathrm{NH}_{3}$ [by mixing $5 \mathrm{~mL}$ of the filtrate with $1 \mathrm{~mL}$ of $1 \%$ (wt/ vol) $\mathrm{H}_{2} \mathrm{SO}_{4}$ ]. Another $5 \mathrm{~mL}$ of the filtrate was mixed with $10 \mathrm{~mL}$ of methyl green-formalin-saline solution for protozoal quantification. Those samples were stored at
20 to $25^{\circ} \mathrm{C}$ with no exposure to natural or artificial light until analyzed.

Ruminal pH was measured continuously every $30 \mathrm{~s}$ for $6 \mathrm{~d}$ using the Lethbridge Research Center Ruminal pH Measurement System (LRCpH; Dascor, Escondido, CA) as described by Penner et al. (2006). The system was calibrated at the start and end of the measurement period. Production of enteric $\mathrm{CH}_{4}$ gas was measured from individual cows for $3 \mathrm{~d}$ using the sulfur hexafluoride $\left(\mathrm{SF}_{6}\right)$ tracer gas technique with halters and polyvinyl chloride yokes (Johnson et al., 1994) according to McGinn et al. (2009). The permeation tubes $(12.5 \times 40$ $\mathrm{mm}$ ) contained $2,562 \mathrm{mg} \pm 36.9 \mathrm{SD}$ of ultra-pure $\mathrm{SF}_{6}$ and were placed in the rumen at least $1 \mathrm{wk}$ before the start of the experiment. The release rates for $\mathrm{SF}_{6}$ were from 2.9 to $3.3 \mathrm{mg}$ of $\mathrm{SF}_{6} / \mathrm{d}$ with a mean release rate of $3.1 \mathrm{mg} \pm 0.15 \mathrm{SD} \mathrm{SF}_{6} / \mathrm{d}$. A halter and a yoke canister were placed on the animal daily immediately before feeding. Background levels of $\mathrm{SF}_{6}$ and $\mathrm{CH}_{4}$ were measured by suspending yokes near the ventilation systems. Yoke canisters including the background canisters were removed at $24 \mathrm{~h}$ and sampled with a syringe.

\section{Laboratory Analyses}

Weekly refusals, experimental diets, and dietary ingredients were measured for DM contents by drying for $48 \mathrm{~h}$ at $60^{\circ} \mathrm{C}$ in a forced air oven. Dry matter contents of ingredients were used to adjust the forage to concentrate ratio of the experimental diets and the amount of enzyme added. Dry matter contents of experimental diets and refusals were used to calculate DMI. The basal diet and dietary ingredients from each period were analyzed for contents of analytical DM, OM, CP, NDF, and ADF (Table 1). Gross energy (GE) contents of the experimental diets were determined using a bomb calorimeter (model E2k; CAL2k, Johannesburg, South Africa). Details of feed sample preparation and analytical methods were reported in Holtshausen et al. (2011).

Concentrations of VFA in ruminal fluid were quantified using gas chromatography (model 5890; Hewlett Packard, Wilmington, DE) and $\mathrm{NH}_{3}$ determined by the salicylate-nitroprusside-hypochlorite method using a flow injection analyzer (Sims et al., 1995). Concentrations of $\mathrm{SF}_{6}$ and $\mathrm{CH}_{4}$ in gas samples from the yoke canisters were analyzed using gas chromatography (model 5890; Agilent Technologies, Santa Clara, CA) with flame-ionization detection for $\mathrm{CH}_{4}$ and electron capture detection for $\mathrm{SF}_{6}$. Standard curves for the gas chromatography were generated throughout the study using 5 gas standards between 18.3 and $299.5 \mathrm{nmol} /$ $\mathrm{mol}$ for $\mathrm{SF}_{6}$ and between 1.6 and $250 \mu \mathrm{mol} / \mathrm{mol}$ for $\mathrm{CH}_{4}$. The correlation coefficient exceeded $99.9 \%$ for all 
curves. Details of gas chromatography conditions for VFA and gas analyses are in Chung et al. (2011).

Ruminal protozoa in filtered ruminal fluid were counted using a counting chamber (Neubauer Improved Bright-Line counting cell, $0.1 \mathrm{~mm}$ depth; Hausser Scientific, Horsham, PA) and a light microscope (Ogimoto and Imai, 1981). Duplicate preparations (2 counts per preparation) of each sample were counted (5 out of 9 cells were counted per count) and if either value differed from the average by more than $10 \%$, a third preparation of the sample was counted.

For quantifications of ruminal methanogens, total DNA was extracted from filtered ruminal fluid as described previously (Guan et al., 2008) with modifications. Briefly, ruminal fluid $(2 \mathrm{~mL})$ was thawed on ice and added to $4 \mathrm{~mL}$ of a wash-buffer solution (10 $\mathrm{mmol} / \mathrm{L}$ Tris- $\mathrm{HCl}$ at $\mathrm{pH}=8.0$ with $150 \mathrm{mmol} / \mathrm{L} \mathrm{NaCl}$ ). The mixture was vortexed for $30 \mathrm{~s}$ and centrifuged at $200 \times g$ for $5 \mathrm{~min}$ at $4^{\circ} \mathrm{C}$ to separate finer feed particles. One milliliter of the supernatant was transferred and subjected to bead beating (Mini Bead-Beater-8; BioSpec, Bartlesville, OK) to lyse microbial cells in the supernatant. Total DNA was extracted by mixing the supernatant with a mixture of phenol-chloroform-isoamyl alcohol (25:24:1) after physical disruption. Extracted DNA was precipitated in $500 \mu \mathrm{L}$ of cold ethanol, resuspended in $40 \mu \mathrm{L}$ of nuclease-free water, and stored at $-20^{\circ} \mathrm{C}$ for further analysis. Quantitative real-time PCR was conducted to quantify archaeal $16 S-r R N A$ gene using Fast SYBR Green Master Mix kit and StepOnePlus Real-Time PCR System (Applied Biosystems by Life Technologies Corp., Carlsbad, CA). Reaction system, standard curves, and running conditions were reported in Zhou et al. (2009).

For bacteria analysis, extraction of DNA was performed as described previously (Alexander et al., 2011). Briefly, filtered rumen fluid containing finer feed particles and liquid- and solid-associated bacteria was freeze-dried and then ground to a powder using a planetary micro mill (Retsch, Albisheim, Germany). Thirty milligrams of dried rumen fluid was weighed and DNA was extracted using a Qiagen QIAamp DNA Stool Mini Kit (Qiagen Inc., Mississauga, ON, Canada) according to the manufacturer's instructions, with the following exception: bacteria were lysed at $95^{\circ} \mathrm{C}$ for $10 \mathrm{~min}$. DNA was quantified fluorometrically using the Quant-iT PicoGreen dsDNA Assay Kit (Invitrogen, Burlington, ON, Canada) with a VersaFluor fluorometer (Bio-Rad, Mississauga, ON, Canada).

Real-time PCR was used to quantify $16 S-r R N A$ for total bacteria and sequences specific to Fibrobacter succinogenes, Prevotella bryantii, Ruminobacter amylophilus, Ruminococcus albus, Ruminococcus flavefaciens, Selenomonas ruminantium, and Streptococcus bovis.
Primers and annealing temperatures were described previously for F. succinogenes, P. bryantii, R. amylophilus, $R$. flavefaciens, Sel. ruminantium, and Strep. bovis (Tajima et al., 2001), R. albus (Wang et al., 1997), and universal (Nadkarni et al., 2002) 16S-rRNA. For the PCR, 40 ng of extracted DNA template was added. The PCR cycling conditions, plasmid standards, and reference bacterial strains have been described previously (Wang et al., 2009). Copies of species-specific $16 S$ $r R N A$ were normalized to total 16S-rRNA, and the ratios were used to estimate abundance of bacterial populations.

\section{Calculation and Statistical Analysis}

The $\mathrm{SF}_{6}$ release rates of the permeation tubes did not differ $(P>0.05)$ among treatment groups; thus, the $\mathrm{CH}_{4}$ data were not covariate-adjusted for the pre-deployment $\mathrm{SF}_{6}$ release rate. Population densities of protozoa and methanogens were $\log _{10}$ transformed before statistical analysis with the inverse $\log _{10}$ LSM reported. Data for continuous ruminal $\mathrm{pH}$ measurement were summarized by day according to Dohme et al. (2008) before statistical analysis. Milk production and DMI were analyzed using the weekly means that were measured during the sampling week of each period.

Data were analyzed using the mixed model procedure (SAS Institute, 1999). Cow was the experimental unit for all variables. The full general linear mixed model included the fixed effects of square, period nested within square, treatment (control, low, or high enzyme), sampling time (day or hour within a day), and the interaction of treatment and sampling time. For milk production and DMI, the fixed effect of sampling time and its related interaction were removed from the full general linear mixed model. For all data, if the interaction of treatment by sampling time was not significant $(P>$ 0.05), the fixed effect of sampling time and its related interaction were removed from the full model. Time of sampling was considered a repeated effect (or double repeated effect for ruminal VFA, $\mathrm{NH}_{3}$, and protozoa) in the model. Cow nested within square was used in the random statement. Denominator degrees of freedom were estimated using the Kenward-Roger option in the model statement. If the effect of enzyme treatment for a variable was significant $(P \leq 0.10)$, the treatment LSM was compared with control LSM using the PDIFF option adjusted by the Dunnett method in the lsmeans statement. Time-series covariance structure was modeled using various options and the best time series covariance structure was selected based on the lowest Akaike and Bayesian information criteria. Linear and quadratic dependent variable responses to increasing levels of enzyme in the diet were determined using 
Table 2. Ruminal VFA and $\mathrm{NH}_{3}$ in lactating Holstein cows fed a diet supplemented with a low $(0.5 \mathrm{~mL} / \mathrm{kg}$ of TMR DM) or high (1.0 mL/kg of TMR DM) dose of fibrolytic enzyme additive

\begin{tabular}{lccccc}
\hline Variable & Control & $\begin{array}{c}\text { Low } \\
\text { enzyme }\end{array}$ & $\begin{array}{c}\text { High } \\
\text { enzyme }\end{array}$ & SEM & $\begin{array}{c}\text { Treatment effect, } \\
P \text {-value }\end{array}$ \\
\hline Total VFA, mM & 139 & 143 & 141 & 7.1 & 0.92 \\
Individual VFA, mol/100 mol & & & & & \\
$\quad$ Acetate (A) & 61.6 & 60.2 & 61.0 & 1.15 & 0.67 \\
Propionate (P) & 23.0 & 23.3 & 22.7 & 1.14 & 0.92 \\
Butyrate & 11.4 & 11.4 & 12.1 & 0.38 & 0.27 \\
Isobutyrate & 1.1 & 1.1 & 1.1 & 0.06 & 0.99 \\
Valerate & 1.8 & 1.8 & 1.9 & 0.09 & 0.25 \\
Isovalerate & 1.3 & 1.3 & 1.4 & 0.08 & 0.57 \\
Caproate & 0.35 & 0.33 & 0.37 & 0.028 & 0.49 \\
A:P ratio & 2.7 & 2.6 & 2.7 & 0.16 & 0.75 \\
$\mathrm{NH}_{3}, \mathrm{~m} M$ & 5.8 & 6.4 & 5.9 & 0.33 & 0.39 \\
\hline
\end{tabular}

orthogonal polynomial contrasts. Data are presented as means \pm standard deviations or LSM \pm standard errors or standard error of the means. Differences were declared significant at $P \leq 0.05$, and a tendency to significance was declared at $0.05<P \leq 0.10$.

\section{RESULTS AND DISCUSSION}

\section{DMI and Milk Yield}

Body weights and BCS were similar among treatment groups throughout the experiment, averaging $616 \mathrm{~kg}$ $( \pm 14.0 \mathrm{SE})$ for BW and 2.7 ( $\pm 0.07 \mathrm{SE} ; 1$ to 5 scale) for BCS. On the days of $\mathrm{CH}_{4}$ measurement, DMI was not affected by enzyme, averaging $25.6,24.4$, and $25.5 \mathrm{~kg} / \mathrm{d}$ $( \pm 1.62 \mathrm{SEM})$ for the control, low, and high enzyme diet, respectively. Yields of milk or 3.5\% FCM that were obtained from the sampling week of each period were also not affected by enzyme, averaging 37.7, 38.2, and $38.0 \mathrm{~kg}$ of milk/d $( \pm 1.52 \mathrm{SEM})$ or $35.7,36.1$, and $36.3 \mathrm{~kg}$ of $3.5 \% \mathrm{FCM} / \mathrm{d}( \pm 1.76 \mathrm{SEM})$ for the control, low, and high enzyme diets, respectively.

Recently, Holtshausen et al. (2011) reported improved production efficiencies of milk or FCM using this exogenous fibrolytic enzyme additive added to the TMR at the same dosages as used in the present study. In Holtshausen et al. (2011), the improvement in production efficiency with enzyme addition, especially at $1.0 \mathrm{~mL}$ of enzyme $/ \mathrm{kg}$ of TMR DM, resulted from a lower level of DMI with no change in milk production. Similar improvements in milk production efficiency were reported by Arriola et al. (2011) for another enzyme additive. Although we used the same basal diet and same batch of enzyme as Holtshausen et al. (2011), in the present study, enzyme addition did not affect milk production efficiency or DMI and milk production. The Latin square design and relatively short periods (3 wk per period) used in our study compared with a complete randomized block design with 9- to 10-wk periods used by Holtshausen et al. (2011) and Arriola et al. (2011) may be inadequate for evaluating effects of the enzyme treatment on milk production efficiency.

\section{Ruminal VFA, $\mathrm{NH}_{3}$, and $\mathrm{pH}$}

Adding enzyme to the diet did not affect ruminal fluid concentrations of total VFA and $\mathrm{NH}_{3}$ or molar proportions of individual VFA (Table 2). Concentrations of total VFA and $\mathrm{NH}_{3}$ and molar proportions of individual VFA in ruminal fluid changed after feeding (hour effect: $P<0.01$; data not shown). However, no interactions of treatment by sampling time were observed for ruminal VFA or $\mathrm{NH}_{3}$.

The effects of enzyme feed additives on ruminal fermentation seem to be inconsistent in the literature, even for studies reporting increased digestibility with the addition of fibrolytic enzymes. For example, Arriola et al. (2011) reported an increase in total VFA concentration and a decrease in the acetate:propionate ratio in ruminal fluid. Gado et al. (2009) and Beauchemin et al. (2000) reported an increase in the proportion of acetate in ruminal fluid by fibrolytic enzymes, whereas Beauchemin et al. (1999) and Yang et al. (1999) reported no effect of fibrolytic enzymes on ruminal fermentation.

Dietary addition of enzyme also had no effect on ruminal $\mathrm{pH}$ variables (Table 3). The minimum and maximum $\mathrm{pH}$ and the daily fluctuations of ruminal $\mathrm{pH}$ from the maximum to minimum were similar among treatments. Cows used in this study experienced periods of moderate ruminal acidosis (ruminal $\mathrm{pH}<5.8$ ). However, the duration (h/d) and severity (indicated by area between $\mathrm{pH} 5.8$ and the $\mathrm{pH}$ profile of the cow) of ruminal acidosis did not differ among treatments averaging $4.2 \mathrm{~h} / \mathrm{d}( \pm 0.35 \mathrm{SE})$ for duration and $45.6 \mathrm{pH}$ units $\times \min / \mathrm{d}( \pm 5.47 \mathrm{SE})$ for severity. 
Table 3. Ruminal $\mathrm{pH}$ variables measured continuously for $6 \mathrm{~d}$ in lactating Holstein cows fed a diet supplemented with a low $(0.5 \mathrm{~mL} / \mathrm{kg}$ of TMR DM) or high $(1.0 \mathrm{~mL} / \mathrm{kg}$ of TMR DM) dose of fibrolytic enzyme additive

\begin{tabular}{lccccc}
\hline Variable & Control & $\begin{array}{c}\text { Low } \\
\text { enzyme }\end{array}$ & $\begin{array}{c}\text { High } \\
\text { enzyme }\end{array}$ & SEM & $\begin{array}{c}\text { Treatment effect, } \\
P \text {-value }\end{array}$ \\
\hline Minimum ruminal pH & 5.59 & 5.59 & 5.58 & 0.067 & 0.95 \\
Mean ruminal pH & 6.17 & 6.12 & 6.13 & 0.052 & 0.15 \\
Maximum ruminal pH & 6.77 & 6.66 & 6.74 & 0.043 & 0.11 \\
Range & 1.20 & 1.12 & 1.16 & 0.049 & 0.31 \\
Ruminal pH $<5.8$ & 4.2 & 4.2 & 4.1 & 1.33 & 1.00 \\
Duration, $\mathrm{h} / \mathrm{d}$ & 45.0 & 40.9 & 50.8 & 19.81 & 0.82 \\
Area, $\mathrm{pH}$ units $\times \mathrm{min} / \mathrm{d}$ & 9 & 11 & 9 & 1.8 & 0.65 \\
Bouts, no./d & & & & \\
\hline
\end{tabular}

${ }^{1}$ Range $=$ maximum rumen $\mathrm{pH}-$ minimum ruminal $\mathrm{pH}$

\section{Microbial Population Density in Ruminal Fluid}

Population densities of total protozoa, bacteria, and methanogens in ruminal fluid were not affected by enzyme addition (Table 4). However, population densities of certain bacteria, calculated as copy number of species-specific 16S-rRNA genes, were affected by enzyme treatment. The ruminal fibrolytic bacterium $F$. succinogenes (linear effect: $P=0.05$ ) and the nonfibrolytic bacteria $R$. amylophilus (linear effect: $P=$ 0.01 ) and Sel. ruminantium (linear effect: $P=0.10$ ) increased or tended to increase linearly with increasing levels of enzyme in the diet. Population densities for $F$. succinogenes were 1.7-fold higher (high enzyme vs. control: $P=0.10$; treatment effect: $P=0.06)$ and $R$. amylophilus were 1.3-fold higher (high enzyme vs. control: $P=0.02$; treatment effect: $P=0.03)$ for the high-enzyme treatment compared with the control. The nonfibrolytic bacterium Strep. bovis, however, was quadratically affected $(P=0.03)$ by increasing levels of enzyme in the diet, with population density tending $(P=0.08)$ to be lower for the low enzyme treatment versus control. Time relative to feeding affected the population densities of protozoa and bacteria in ruminal fluid (hour effect: $P \leq 0.05$ ) but this effect was consistent for all treatments. In contrast, time relative to feeding did not influence the population density of ruminal methanogens.

Stimulation of rumen microbial populations has been proposed as a potential mode of action by which exogenous fibrolytic enzymes increase feed digestion and improve animal production (Beauchemin et al., 2003).

Table 4. Population densities of protozoa, bacteria, and methanogens in ruminal fluid from lactating Holstein cows fed a diet supplemented with a low $(0.5 \mathrm{~mL} / \mathrm{kg}$ of TMR DM) or high $(1.0 \mathrm{~mL} / \mathrm{kg}$ of TMR DM) dose of fibrolytic enzyme additive

\begin{tabular}{|c|c|c|c|c|c|}
\hline Variable & Control & $\begin{array}{c}\text { Low } \\
\text { enzyme }\end{array}$ & $\begin{array}{c}\text { High } \\
\text { enzyme }\end{array}$ & SEM & $\begin{array}{c}\text { Treatment } \\
\text { effect, } \\
P \text {-value }\end{array}$ \\
\hline Total protozoa, $\times 10^{5} \mathrm{cell} / \mathrm{mL}$ of rumen fluid & 3.8 & 4.0 & 3.8 & 0.41 & $0.98^{1}$ \\
\hline Fibrobacter succinogenes, ${ }^{4} \times 10^{5}$ & 1.9 & 1.7 & $3.2 \ddagger$ & 0.45 & 0.06 \\
\hline Ruminobacter amylophilus, ${ }_{,}^{4} \times 10^{3}$ & 2.1 & 2.2 & $2.8 \dagger$ & 0.21 & 0.03 \\
\hline Selenomonas ruminantium ${ }^{5} \times 10^{4}$ & 2.4 & 2.4 & 3.2 & 0.34 & 0.19 \\
\hline Streptococcus bovis, $\times 10^{3}$ & 1.7 & $1.3 \ddagger$ & 1.6 & 0.46 & 0.09 \\
\hline Total methanogens, ${ }^{3} \times 10^{8}$ copies of archaeal $16 S-r R N A / \mathrm{mL}$ of rumen fluid & 6.2 & 12.1 & 4.6 & 4.43 & $0.43^{1}$ \\
\hline
\end{tabular}

${ }^{1}$ Probability of the treatment effect on total protozoa and methanogens was calculated based on $\log _{10}$ conversion of population densities, which are reported as inverse $\log _{10}$ LSM in the table.

${ }^{2}$ Population densities for bacteria were measured only in samples taken on d 19 of each period.

${ }^{3}$ Copies of bacterial or archaeal $16 S-r R N A$ were quantified by real-time PCR and used to estimate bacterial or methanogenic populations, respectively.

${ }^{4}$ Linear effect with increasing enzyme doses; $P \leq 0.05$.

${ }^{5}$ Tendency to a linear effect with increasing enzyme doses; $0.5<P \leq 0.10$.

$\dagger$ Treatment LSM differed from control LSM; $P \leq 0.05$. Treatment LSM was compared against the control with the PDIFF command invoked and using the Dunnett adjustment.

$\ddagger$ Treatment LSM tended to differ from control LSM; $0.05<P \leq 0.10$. 
Table 5. Enteric methane $\left(\mathrm{CH}_{4}\right)$ emissions from lactating Holstein cows fed a diet supplemented with a low $(0.5 \mathrm{~mL} / \mathrm{kg}$ of TMR DM) or high $(1.0 \mathrm{~mL} / \mathrm{kg}$ of TMR DM) dose of fibrolytic enzyme additive

\begin{tabular}{|c|c|c|c|c|c|}
\hline Variable & Control & $\begin{array}{c}\text { Low } \\
\text { enzyme }\end{array}$ & $\begin{array}{c}\text { High } \\
\text { enzyme }\end{array}$ & SEM & $\begin{array}{c}\text { Treatment effect, } \\
P \text {-value }\end{array}$ \\
\hline $\mathrm{CH}_{4}, \mathrm{~g} /$ animal per day ${ }^{1}$ & 471 & 505 & $545 \ddagger$ & 31.2 & 0.10 \\
\hline $\mathrm{CH}_{4}, \mathrm{~g} / \mathrm{kg}$ of $\mathrm{DMI}^{1,2}$ & 19.3 & 20.8 & $21.7 \dagger$ & 1.12 & 0.04 \\
\hline $\mathrm{CH}_{4}, \mathrm{~g} / \mathrm{kg}$ of $\mathrm{MY}^{1,2}$ & 12.9 & 13.6 & $15.1 \dagger$ & 0.97 & 0.02 \\
\hline $\mathrm{CH}_{4}, \mathrm{~g} / \mathrm{kg}$ of $\mathrm{FCM}^{1,2}$ & 13.4 & 14.3 & 15.5 & 0.96 & 0.13 \\
\hline Percentage GE intake $^{1,2}$ & 6.5 & 6.9 & $7.2 \dagger$ & 0.38 & 0.06 \\
\hline
\end{tabular}

${ }^{1}$ Linear trend with increasing enzyme doses; $P \leq 0.05$.

${ }^{2}$ Enteric $\mathrm{CH}_{4}$ production ( $\mathrm{g}$ of $\mathrm{CH}_{4}$ /animal per day) expressed relative to DMI determined on the days of $\mathrm{CH}_{4}$ measurement, yields $(\mathrm{kg} / \mathrm{d})$ of milk $(\mathrm{MY})$, or $3.5 \%$ FCM produced during the sampling week of each period or gross energy (GE) intake on the days of $\mathrm{CH}_{4}$ measurement.

$\dagger$ Treatment LSM differed from control LSM; $P \leq 0.05$. Treatment LSM was compared against the control with the PDIFF command invoked and using the Dunnett adjustment.

$\ddagger$ Treatment LSM tended to differ from control LSM; $0.05<P \leq 0.10$.

Nsereko et al. (2002) reported increased numbers of total bacteria and cellobiose-utilizing bacteria in dairy cows fed a high concentrate diet ( $52 \%$ diet DM) supplemented with enzymes. Giraldo et al. (2008b) reported an increase in the number of cellulolytic bacteria in sheep fed an enzyme-treated, high forage diet $(70 \%$ diet DM). Exogenous enzymes were also reported to increase the number of total bacteria (Giraldo et al., 2007) or cellulolytic bacteria (Wang et al., 2001) in vitro using the RUSITEC technique.

Adding exogenous enzymes to the TMR prefeeding appears to increase the availability of feed nutrients to ruminal microbes, as evidenced by increased attachment and colonization of ruminal microbes to feed particles (Wang et al., 2001). A linear increase in population density for $R$. amylophilus and a tendency for a linear increase in population density for Sel. ruminantium observed in the current study could be related to a linear increase in $F$. succinogenes with increasing enzyme dosage in the diet. Fermentation products from primary digesters, such as $F$. succinogenes, can attract secondary digesters, such as R. amylophilus and Sel. ruminantium to attach to and colonize feed particles (Cheng and McAllister, 1997). It is unknown why Strep. bovis decreased in the low enzyme treatment but not in the high enzyme treatment. However, the lower population density observed for Strep. bovis did not affect ruminal fermentation for the low enzyme treatment compared with control.

Little information exists on the effects of exogenous enzymes on ruminal protozoa and methanogens. Enzyme additives had no effect on protozoa in the present study or in the study by Wang et al. (2001), who evaluated another enzyme additive. Exogenous enzymes increased the number of methanogens in vitro (Dong et al., 1999), but that was not the case in the present study, in which a different enzyme additive was used.
Although the population density of ruminal methanogens was not affected by enzyme, species composition of ruminal methanogens was different between treatments in the present study [data were reported in a companion study by Zhou et al. (2011)].

\section{Enteric Methane Emissions}

Increasing the dosage of enzyme supplement increased enteric $\mathrm{CH}_{4}$ production, even when adjusted for feed intake, milk production, or GE intake (linear effect: $P \leq 0.05$; Table 5). Compared with the control diet, adding a high level of enzyme to the diet increased enteric production of $\mathrm{CH}_{4}$ (g/head per day) by $16 \%$ $(P=0.07)$ or by $12,17,16$, or $12 \%$ after adjusting $\mathrm{CH}_{4}$ production for DMI $(P=0.03)$, milk yield $(P=$ $0.01), 3.5 \%$ FCM $(P=0.09)$, or GE intake $(P=0.04)$, respectively.

The observed $\mathrm{CH}_{4}$ production from the present study may seem to be high. However, after correcting $\mathrm{CH}_{4}$ production for the amount of milk produced, the observed $\mathrm{CH}_{4}$ production per unit of milk from cows on the control diet was comparable to that reported in the literature. Holtshausen et al. (2009) reported an intensity of $11.6 \mathrm{~g}$ of $\mathrm{CH}_{4} / \mathrm{kg}$ milk for multiparous cows on a control diet using the $\mathrm{SF}_{6}$ technique, which is similar to the intensity of $11.8 \mathrm{~g}$ of $\mathrm{CH}_{4} / \mathrm{kg}$ of milk reported for multiparous cows on the control diet in our study. Beauchemin et al. (2009) reported a lower intensity of $11.7 \mathrm{~g}$ of $\mathrm{CH}_{4} / \mathrm{kg}$ of $\mathrm{FCM}$ for primiparous cows fed a control diet compared with an intensity of $13.5 \mathrm{~g}$ of $\mathrm{CH}_{4} / \mathrm{kg}$ of FCM reported for primiparous cows fed the control diet in our study. The chamber technique was used in Beauchemin et al. (2009). Martin et al. (2008) and Lovett et al. (2005) reported higher $\mathrm{CH}_{4}$ production per unit milk basis, from 17.4 to $19.6 \mathrm{~g}$ of $\mathrm{CH}_{4} / \mathrm{kg}$ of milk, than the current study, likely due to a higher 
proportion $(>65 \%)$ of forage in the diets used in their studies. The $\mathrm{SF}_{6}$ technique was used by both Martin et al. (2008) and Lovett et al. (2005).

A limited body of information describes the effects of enzyme additives on enteric $\mathrm{CH}_{4}$ emissions from dairy cows. McGinn et al. (2004) reported no effects of a proteolytic enzyme additive on enteric $\mathrm{CH}_{4}$ emissions. Arriola et al. (2011) fed a fibrolytic enzyme to dairy cows and estimated a reduction in $\mathrm{CH}_{4}$ production based on ruminal fermentative pattern (a lower acetate to propionate ratio in ruminal fluid by enzyme), but $\mathrm{CH}_{4}$ was not directly measured. In vitro studies (Eun et al., 2007; Eun and Beauchemin, 2007) reporting improved fiber degradation by fibrolytic enzymes often reported a concurrent decrease in acetate:propionate ratio in the fermentation fluid. Based on this observation, Beauchemin et al. (2008) proposed that dietary enzyme feed additives may help mitigate enteric $\mathrm{CH}_{4}$ emissions. However, the increased production of enteric $\mathrm{CH}_{4}$ with increasing levels of enzyme observed in the present study do not support the use of enzymes for enteric $\mathrm{CH}_{4}$ mitigation and reinforces the need for in vivo evaluation with direct measurement of $\mathrm{CH}_{4}$ emissions.

An increase in $\mathrm{CH}_{4}$ production with increasing enzyme dosage indicates that more energy was lost as $\mathrm{CH}_{4}$ during ruminal fermentation, a finding that may intuitively seem to be at odds with the observed concurrent increase in feed conversion observed by Holtshausen et al. (2011). However, in the study by Holtshausen et al. (2011), increased feed conversion was due to lower DMI that occurred after 5 wk of feeding, and thus, this effect could not be substantiated in a short-term study. It is possible that the increase in feed conversion was due to a change in microbial communities, as reported in the present study. Our results indicate that dietary supplementation with exogenous enzymes caused shifts in ruminal bacterial communities, without an increase in the overall densities of protozoa, bacteria, or methanogens or a change in VFA or pH profile in the rumen, although changes in methanogenic species occurred (Zhou et al., 2011). However, the long-term effect of this fibrolytic enzyme on ruminal variables and enteric $\mathrm{CH}_{4}$ production still need to be evaluated.

\section{CONCLUSIONS}

Addition of an exogenous fibrolytic enzyme additive to the diet of lactating Holstein cows did not alter ruminal fermentation or rumen $\mathrm{pH}$. However, increasing the level of enzyme additive in the diet linearly increased population densities of certain bacterial species and enteric $\mathrm{CH}_{4}$ production, even when adjusted for changes in feed intake or milk production. More research using longer term studies is needed for this exogenous fibrolytic enzyme additive to establish whether the observed shift in ruminal bacterial communities improves feed conversion efficiency of dairy cows.

\section{ACKNOWLEDGMENTS}

The authors are grateful to B. Farr and H. GerardoCuervo for sampling, C. Klima and S. Cook for bacterial analysis, D. Vedres for GC analysis (all of Agriculture and Agri-Food Canada, Lethbridge, AB, Canada), and the staff at the Dairy Research \& Technology Centre (University of Alberta, Edmonton, AB, Canada) for feeding and caring of the cows. The authors also thank N. D. Walker (AB Vista, Marlborough, Wiltshire, UK) for comments on the manuscript. Funding for the study was from Agricultural and Agri-Food Canada, Dairy Farmers of Canada, and AB Vista.

\section{REFERENCES}

Alexander, T. W., J. L. Yanke, T. Reuter, E. Topp, R. R. Read, B. L. Selinger, and T. A. McAllister. 2011. Longitudinal characterization of antimicrobial resistance genes in feces shed from cattle fed different subtherapeutic antibiotics. BMC Microbiol. 11:19.

Arriola, K. G., S. C. Kim, C. R. Staples, and A. T. Adesogan. 2011. Effect of fibrolytic enzyme application to low- and high-concentrate diets on the performance of lactating dairy cattle. J. Dairy Sci. 94:832-841.

Beauchemin, K. A., D. Colombatto, D. P. Morgavi, and W. Z. Yang. 2003. Use of exogenous fibrolytic enzymes to improve feed utilization by ruminants. J. Anim. Sci. 81(E. Suppl.):E37-E47.

Beauchemin, K. A., and L. Holtshausen. 2011. Developments in enzyme usage in ruminants. Pages 206-230 in Enzymes in Farm Animal Nutrition. M. R. Bedford and G. G. Partridge, ed. CABI Publ., Wallingford, UK.

Beauchemin, K. A., M. Kreuzer, F. O'Mara, and T. A. McAllister. 2008. Nutritional management for enteric methane abatement: A review. Aust. J. Exp. Agric. 48:21-27.

Beauchemin, K. A., S. M. McGinn, C. Benchaar, and L. Holtshausen. 2009. Crushed sunflower, flax, or canola seeds in lactating dairy cow diets: Effects on methane production, rumen fermentation, and milk production. J. Dairy Sci. 92:2118-2127.

Beauchemin, K. A., L. M. Rode, M. Maekawa, D. P. Morgavi, and R. Kampen. 2000. Evaluation of a nonstarch polysaccharidase feed enzyme in dairy cow diets. J. Dairy Sci. 83:543-553.

Beauchemin, K. A., W. Z. Yang, and L. M. Rode. 1999. Effects of grain source and enzyme additive on site and extent of nutrient digestion in dairy cows. J. Dairy Sci. 82:378-390.

Cheng, K.-J., and T. A. McAllister. 1997. Compartmentation in the rumen. Pages 492-522 in The Rumen Microbial Ecosystem. P. N. Hobson and C. S. Stewart, ed. Blackie Academic \& Professional, London, UK.

Chung, Y.-H., N. D. Walker, S. M. McGinn, and K. A. Beauchemin. 2011. Differing effects of 2 active dried yeast (Saccharomyces cerevisiae) strains on ruminal acidosis and methane production in nonlactating dairy cows. J. Dairy Sci. 94:2431-2439.

Dohme, F., T. J. DeVries, and K. A. Beauchemin. 2008. Repeated ruminal acidosis challenges in lactating dairy cows at high and low risk for developing acidosis: Ruminal pH. J. Dairy Sci. 91:35543567.

Dong, Y., H. D. Bae, T. A. McAllister, G. W. Mathison, and K.J. Cheng. 1999. Effects of exogenous fibrolytic enzymes, 
$\alpha$-bromoethanesulfonate and monensin on fermentation in a rumen simulation (RUSITEC) system. Can. J. Anim. Sci. 79:491-498.

Eun, J.-S., and K. A. Beauchemin. 2007. Enhancing in vitro degradation of alfalfa hay and corn silage using feed enzymes. J. Dairy Sci. 90:2839-2851.

Eun, J.-S., K. A. Beauchemin, and H. Schulze. 2007. Use of exogenous fibrolytic enzymes to enhance in vitro fermentation of alfalfa hay and corn silage. J. Dairy Sci. 90:1440-1451.

Gado, H. M., A. Z. M. Salem, P. H. Robinson, and M. Hassan. 2009 Influence of exogenous enzymes on nutrient digestibility, extent of ruminal fermentation as well as milk production and composition in dairy cows. Anim. Feed Sci. Technol. 154:36-46.

Giraldo, L. A., M. J. Ranilla, M. L. Tejido, and M. D. Carro. 2007. Influence of exogenous fibrolytic enzymes and fumarate on methane production, microbial growth and fermentation in Rusitec fermenters. Br. J. Nutr. 98:753-761.

Giraldo, L. A., M. L. Tejido, M. J. Ranilla, and M. D. Carro. 2008a. Effects of exogenous fibrolytic enzymes on in vitro ruminal fermentation of substrates with different forage:concentrate ratios. Anim. Feed Sci. Technol. 141:306-325.

Giraldo, L. A., M. L. Tejido, M. J. Ranilla, S. Ramos, and M. D. Carro. 2008b. Influence of direct-fed fibrolytic enzymes on diet digestibility and ruminal activity in sheep fed a grass hay-based diet. J. Anim. Sci. 86:1617-1623.

Guan, L. L., J. D. Nkrumah, J. A. Basarab, and S. S. Moore. 2008. Linkage of microbial ecology to phenotype: Correlation of rumen microbial ecology to cattle's feed efficiency. FEMS Microbiol. Lett. 288:85-91.

Holtshausen, L., A. V. Chaves, K. A. Beauchemin, S. M. McGinn, T. A. McAllister, N. E. Odongo, P. R. Cheeke, and C. Benchaar. 2009. Feeding saponin-containing Yucca schidigera and Quillaja saponaria to decrease enteric methane production in dairy cows. J. Dairy Sci. 92:2809-2821.

Holtshausen, L., Y.-H. Chung, H. Gerardo-Cuervo, M. Oba, and K. A Beauchemin. 2011. Improved milk production efficiency in early lactation dairy cattle with dietary addition of a developmental fibrolytic enzyme additive. J. Dairy Sci. 94:899-907.

Johnson, K. A., M. Huyler, H. Westberg, B. Lamb, and P. Zimmerman. 1994. Measurement of methane emissions from ruminant livestock using a sulfur hexafluoride tracer technique. Environ. Sci. Technol. 28:359-362.

Lovett, D. K., L. J. Stack, S. Lovell, J. Callan, B. Flynn, M. Hawkins, and F. P. O'Mara. 2005. Manipulating enteric methane emissions and animal performance of late-lactation dairy cows through concentrate supplementation at pasture. J. Dairy Sci. 88:2836-2842.

Martin, C., J. Rouel, J. P. Jouany, M. Doreau, and Y. Chilliard. 2008. Methane output and diet digestibility in response to feeding dairy cows crude linseed, extruded linseed, or linseed oil. J. Anim. Sci 86:2642-2650.

McGinn, S. M., K. A. Beauchemin, T. Coates, and D. Colombatto. 2004. Methane emissions from beef cattle: Effects of monensin, sunflower oil, enzymes, yeast, and fumaric acid. J. Anim. Sci. 82:3346-3356.

McGinn, S. M., Y.-H. Chung, K. A. Beauchemin, A. D. Iwaasa, and C. Grainger. 2009. Use of corn distillers dried grains to reduce enteric methane loss from beef cattle. Can. J. Anim. Sci. 89:409-413.
Nadkarni, M. A., F. E. Martin, N. A. Jacques, and N. Hunter. 2002. Determination of bacterial load by real-time PCR using a broadrange (universal) probe and primers set. Microbiology 148:257266.

Nsereko, V. L., K. A. Beauchemin, D. P. Morgavi, L. M. Rode, A. F. Furtado, T. A. McAllister, A. D. Iwaasa, W. Z. Yang, and Y. Wang. 2002. Effect of a fibrolytic enzyme preparation from Trichoderma longibrachiatum on the rumen microbial population of dairy cows. Can. J. Microbiol. 48:14-20.

Ogimoto, K., and S. Imai. 1981. Page 158 in Atlas of Rumen Microbiology. Japan Sci. Soc. Press, Tokyo, Japan.

Penner, G. B., K. A. Beauchemin, and T. Mutsvangwa. 2006. An evaluation of the accuracy and precision of a stand-alone submersible continuous ruminal $\mathrm{pH}$ measurement system. J. Dairy Sci. 89:2132-2140.

SAS Institute. 1999. SAS/STAT User's Guide: Statistics. Version 8 ed. SAS Inst. Inc., Cary, NC.

Sims, G. K., T. R. Ellsworth, and R. L. Mulvaney. 1995. Microscale determination of inorganic nitrogen in water and soil extracts. Commun. Soil Sci. Plant Anal. 26:303-316.

Tajima, K., R. I. Aminov, T. Nagamine, H. Matsui, M. Nakamura, and Y. Benno. 2001. Diet-dependent shifts in the bacterial population of the rumen revealed with real-time PCR. Appl. Environ. Microbiol. 67:2766-2774.

Wang, R. F., W. W. Cao, and C. E. Cerniglia. 1997. PCR detection of Ruminococcus spp. in human and animal faecal samples. Mol. Cell. Probes 11:259-265.

Wang, Y., T. W. Alexander, and T. A. McAllister. 2009. In vitro effects of phlorotannins from Ascophyllum nodosum (brown seaweed) on rumen bacterial populations and fermentation. J. Sci. Food Agric. 89:2252-2260.

Wang, Y., T. A. McAllister, L. M. Rode, K. A. Beauchemin, D. P. Morgavi, V. L. Nsereko, A. D. Iwaasa, and W. Yang. 2001. Effects of an exogenous enzyme preparation on microbial protein synthesis, enzyme activity and attachment to feed in the Rumen Simulation Technique (Rusitec). Br. J. Nutr. 85:325-332.

Wildman, E. E., G. M. Jones, P. E. Wagner, R. L. Boman, H. F. Troutt Jr., and T. N. Lesch. 1982. A dairy cow body condition scoring system and its relationship to selected production characteristics. J. Dairy Sci. 65:495-501.

Yang, W. Z., K. A. Beauchemin, and L. M. Rode. 1999. Effects of an enzyme feed additive on extent of digestion and milk production of lactating dairy cows. J. Dairy Sci. 82:391-403.

Zhou, M., Y.-H. Chung, K. A. Beauchemin, L. Holtshausen, M. Oba, T. A. McAllister, and L.-L. Guan. 2011. Relationship between rumen methanogens and methane production in dairy cows fed diets supplemented with a feed enzyme additive. J. Appl. Microbiol. 111:1148-1158.

Zhou, M., E. Hernandez-Sanabria, and L. L. Guan. 2009. Assessment of the microbial ecology of ruminal methanogens in cattle with different feed efficiencies. Appl. Environ. Microbiol. 75:6524-6533. 